
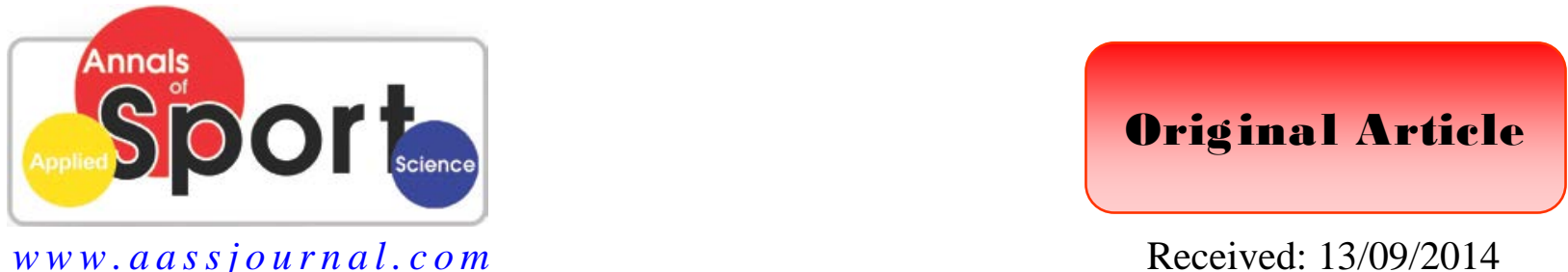

Received: 13/09/2014

ISSN (Online): $2322-4479$

Accepted: 30/04/2015

\title{
Relationship between Motor Skill Competence and Physical Activity in Girls
}

\section{${ }^{1}$ Fatemah Khodaverdi*, Abbas Bahram}

1. Department of Physical Education and Sport Sciences, Education Organization, $9^{\text {th }}$ Region, Tehran, Iran.

2. Department of Motor Behavior, Faculty of Physical Education and Sport Science, Kharazmi University, Tehran, Iran.

\begin{abstract}
This study examined the relationship between motor skill competence, and physical activity in 89 years-old girls $(\mathrm{N}=352)$. Locomotor and object control skill competence was assessed, using the Test of Gross Motor Development-2, and the Physical Activity Questionnaire for Children was used to assess physical activity. Regression analysis revealed that locomotor proficiency accounted for $20 \%(\mathrm{P}=0.001)$ of variance associated with self-reported moderate to vigorous physical activity. The findings warrant future investigations that examine interventions that focus on locomotor skills to promote physical activity in girls.
\end{abstract}

Key Words: Locomotor Skill, Physical Activity, Female, Object Control Skill.

Corresponding Author: 


\section{INTRODUCTION}

The evidence is overwhelming that physical activity (PA) is important for health (1-3). Being active, it has many important short-term health benefits for youth in physical and psycho-social domains (4). Since PA behaviors track to some degree from youth to adulthood (5), there is a concern that inactive youth will become inactive adults. However, Strong et al. (2005) recommended that all school-age youth should participate daily for an hour or more of moderate to vigorous physical activity that is developmentally appropriate practice (DAP), enjoyable, and involves a variety of activities (4). Further, data clearly indicates that girls engage in significantly less PA, compared to their counterparts (6). Thus, there is a critical need to pay attention to patterns and influences of physical activity within this population. This is a major concern globally, and a growing concerns in Middle Eastern countries, due to reports of the increasing prevalence of obesity (7) and physical inactivity in girls (8).

One potential behavioral correlates of children's PA is their motor skill competence (MSC) (9). MSC is defined in terms of proficiency in common fundamental movement skills (10). Fundamental movement skills are the building blocks for more complex motor skills and movement patterns, and represent the underlying performance competency required to participate in many forms of PA (9). They are often divided into two domains: locomotor skills (e.g., run, hop, and jump), and object-control (e.g., catch, throw, and kick). The development of fundamental movement skills competence is prominent in early childhood, and primary school physical education curricula, because of the importance of fundamental movement skills play in children's physical, cognitive, and social development (9).
Studies investigating the relationship between MSC and PA in children and adolescents provide little consensus, with commence in motor skills weakly (11-13) to moderately (12) associated with PA, and explaining as little as $3 \%$, and as much as $25 \%$ (14) of the variance in habitual activity. Differences in the strength of the reported correlations can likely be explained by differences in the age groups examined, and in the measurement of PA (self-parent reports vs. objective measurement), and MSC (product-oriented vs. process-oriented assessment). The relationship between MSC and PA; however, has been investigated rarely in school children. Research study on MSC showed that it was positively associated with sport participation (15), and total PA (16). Further, MSC in all these studies was measured by product-oriented instruments, and one study found positive relationship between process-assessment MSC, and moderate-to-vigorous PA in children (13). At the beginning levels of MSC, product, or outcome of performance are often inconsistent and low, and thus may not adequately differentiate between individuals (17). Examining consistencies in movement patterns, or technique through process-assessment, irrespective of inconsistent performance outcomes, can provide more useful information on MSC in young children (17).

The aim of this cross-sectional study was to examine the relationship between processmeasured MSC, and self-report measured moderate-to-vigorous PA in school girls and to investigate if the relationships differ by fundamental movement skills sub-domains?

\section{MATERIALS AND METHODS}

Participants. Third-grade girls from a state primary school located in the urban southwestern part of Tehran Province (Shahr-e-Qods), Iran, were invited to participate voluntarily in the study. Informed 
parental consent was obtained for 352 girls (mean age $=8.7$ years; $\mathrm{SD}=0.3$ years) and the Institutional Review Board of the corresponding author's university approved the present study. The sample included children in the low-moderate range of socioeconomic background, with no reported history of learning difficulties, or behavioural, physical, neurological, or orthopaedic diagnoses.

Motor skill competence. The Test of Gross Motor Development-2 (TGMD-2) was used to examine motor skill competence (18). The TGMD-2, designed to assess 12 gross motor skills, is subdivided into two areas: locomotor skills (run, gallop, hop, leap, jump, and slide), and object control skills (two-hand strike, stationary bounce, catch, kick, throw, and underhand roll). Each participant skill performance is evaluated, based on qualitative performance criteria, with scores of 1 , or 0 indicating the presence, or absence of each criterion tested. The highest total score for the two subtests is 48 points. Higher raw scores and total score represent higher motor skill competence, while lower scores and total score indicate the absence of critical elements (i.e., motor skill competence) (18). TGMD-2 is valid and reliable for 3-10-year-old Iranian children, and internal consistency coefficients for locomotor, object control, and gross motor quotient includes 0.78, 0.74, and 0.80 , respectively (19).

Physical activity. The Physical Activity Questionnaire for Older Children (PAQ-C) was used to determine the participant's physical activity level (20). PAQ-C requests participants to respond to the physical activity behavior for the past 7 days by asking them to check a list of activities for frequency of participation on a scale from 'no', 1-2 times per week, 3-4, 5-6, to 7 times, or more. Questions are also asked about their physical activity behavior during physical education; recess, at lunch-time, right after school, and evenings, as well as 'the last weekend'. This questionnaire has been supported by a valid and reliable measure and Cronbach's alpha of 0.89 was measured in Iranian children (21).

Procedure. Prior to gathering data, participants and parents/guardians were given written information about nature of the study. Written permission was obtained from the participants and parents/guardians, prior to their child's involvement in the study. All tests occurred during the school day. Firstly, the TGMD-2 was completed on across 4 weeks. Inter-rater reliability $(>90 \%$ agreement) was established for the 2 coders. The PA was assessed with the PAQ-C. This test was also administered during the participant's classroom time. All assessments followed the established procedure, and protocol that was indicated in the training manuals; and all assessments were conducted by one examiner, and one trained assistant.

Statistical Analysis. Pearson's productmoment correlations (r) were used to study the relationship between motor skill competences, and physical activity. Multiple linear regressions were used to determine the best predictor of girls' participation in moderate to vigorous physical activity. Data analysis was conducted using SPSS ver. 16.0 for windows; statistical significance was set at $\mathrm{P}<0.05$.

\section{RESULTS}

Table 1 provides an overview of descriptive statistics. Subjects had higher scores in locomotor skill domain in comparison with object control skill domain (Table 1). For the sample, GMQ was found to marginally relate to moderate-to-vigorous PA outcome $(r=0.39, \mathrm{P}<0.01)$. Further, PA was regressed on locomotor skill, and object control skill sub-domains.

Correlates of Girls’ Moderate to Vigorous Physical Activity. Pearson's correlations showed significant relationships among correlates (Table 2). A stepwise regression 
analysis indicates that locomotor skill vigorous physical activity $(\mathrm{R} 2=0.20$, competence accounted for significant $\mathrm{F}=87.45, \mathrm{P}=0.001$ ) (Table 3). amounts of variance for moderate to

\begin{tabular}{lcc}
\multicolumn{3}{l}{ Table 1: Descriptive data and row scores $(\mathrm{N}=352)$} \\
\hline Variable & Mean & SD \\
Age (year) & 8.78 & 0.32 \\
LS & 41.92 & 6.57 \\
OCS & 34.34 & 5.51 \\
GMQ & $76 / 26$ & $9 / 28$ \\
PA & 3.31 & 0.88 \\
\hline
\end{tabular}

Note: BMI: Body Mass Index; OCS: Object Control Skills; LS: Locomotor Skills; PA: Physical Activity; GMQ: Gross Motor Quation.

Table 2: Correlation (Pearson, two tailed) of girls' moderate to vigorous physical activity participation

\begin{tabular}{lccc}
\hline & PA & LS row scores & OCS row scores \\
LS row scores & $.447^{* *}$ & & \\
OCS row scores & $.135^{*}$ & $.173^{* *}$ & $.71^{* *}$ \\
GMQ & $.39^{* *}$ & $.81^{* *}$ & \\
\hline
\end{tabular}

Note: OCS: Object Control Skills; LS: Locomotor Skills; PA: Physical Activity; GMQ: Gross Motor Quation. ${ }^{*} \mathrm{p}<.05 .{ }^{* *} \mathrm{p}<.001$.

Table 3: Predictors of girl's moderate to vigorous physical activity

\begin{tabular}{cccccc}
\hline Dependent variables & Predictor & R Square & Adjusted R Square & Regression coefficient ( ${ }^{(\boldsymbol{)})}$ & P value \\
& & & & & \\
\hline PA & LS & 0.20 & 0.44 & 0.19 & $0.001^{*}$ \\
\hline${ }^{*} \mathrm{p}<0.01$ & & & & &
\end{tabular}

\section{DISCUSSION and CONCLUSION}

The relationships between MSC include locomotor and object control skills, and selfreport PA were examined in girls. In this study, participants were found to be scored higher for locomotor skills. MSC was positively correlated with self-report PA in children. For girls, locomotor skills, and not object control skills, accounted for variance in PA outcome.

The theoretical basis explaining the mechanism of a positive association between MSC and PA, it was found among girls in the current study, purports that competence in motor skills provides the behavioral proficiency required for participation in variety of PA (9); and may influence other determinants of behaviors, such as, perceptions of competence (22). Children may opt out of opportunities for PA, or may have preference for more sedentary pursuits, in the absence of prerequisite motor competence (23).

This explanation, however, assumes that MSC are the cause rather than consequence of PA, which cannot be inferred from the cross-sectional analyses reported in previous studies in this study. Greater PA opportunities might also provide the context to improve MSC, which is important to 
consider when examining childhood population, where MSC and motor coordination are at the earliest stage of development (24). Longitudinal (25) and experimental studies $(26,27)$, however, have generally been unable to provide evidence of causal relationship between MSC and PA in youth. Further, recent evidence in older children indicates that motor competency in childhood predicts self-report PA in adolescence (28), suggesting that, at some stage of child and adolescent development, competence in motor skills plays a causal role in determining PA behavior (28).

Partitioning fundamental movement skills in sub-domains in the current study and others (11-13), has suggested that locomotor skill relate to girls' $\mathrm{PA}$, and this plausible considering their role in popular activities participated by elementary/primary schoolaged girls, based on facilities in their school. Sallis and Owen (1998) and Sallis et al. (2000) have reported positive association between physical environment variables (access to facilities, programs, time, opportunities to exercise), and child and adolescent PA, with school identified as an important setting in which to promote PA $(29,30)$. In older children, this sub-domain of skills has been shown to relate positively and more strongly to PA (11-13).

The video assessments of MSC using a validated, process-oriented measure, was the method that reduced measurement bias in the current study. Further, fundamental movement skills measure was able to differentiate behavior into meaningful subcategories, allowing for a unique examination of relationship between MSC and PA in girls population.

This study has several limitations. Firstly, the sample selected was from low-tomoderate socioeconomic status and one geographical location. Results can only be generalized to specific populations, Iranian girls. Secondly, PA assessment in current study may have been limited by the use of PAQOC. This questionnaire does not provide an estimate of caloric expenditure, or specific frequency, time, and intensity information and does not discriminate between specific activity intensities (20). Moreover, as PA was assessed during autumn/winter, the data may also have been confounded by seasonal and weather-related variations.

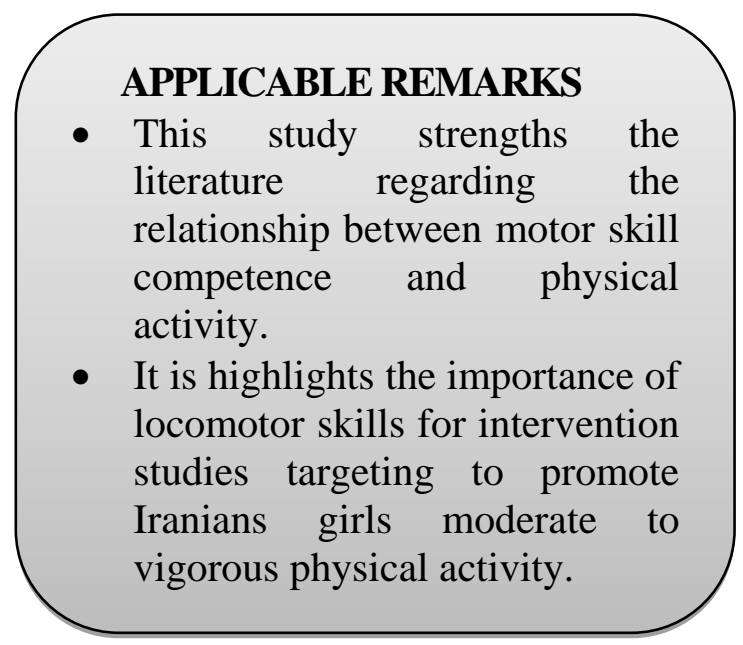

\section{REFFRENCES}

1. Bauman A, Owen N. Physical activity of adult Australians: Epidemiological evidence and potential strategies for health gain. Journal of Science and Medicine in Sport. 1999;2(1):30-41.

2. Blair SN, Kohl HW, 3rd, Paffenbarger RS, Jr., Clark DG, Cooper KH, Gibbons LW. Physical fitness and allcause mortality. A prospective study of healthy men and women. Jama. 1989;262(17):2395-401.

3. US Department of Health \& Human Services. Physical activity and health: A report of the surgeon general. Atlanta, GA: US Department of Health \& Human Services Centers for Disease Control and Prevention National Center for Chronic Disease Prevention and Health Promotion, 1996.

4. Strong WB, Malina RM, Blimkie CJ, Daniels SR, Dishman RK, Gutin B, et al. Evidence based physical activity for school-age youth. The Journal of pediatrics. 2005;146(6):732-7. 
5. Boreham C, Riddoch C. The physical activity, fitness and health of children. Journal of sports sciences. 2001;19(12):915-29.

6. Keller BA. State of the Art Reviews: Development of Fitness in Children: The Influence of Gender and Physical Activity. American Journal of Lifestyle Medicine. 2008;2(1):58-74.

7. Mirmiran P, Sherafat Kazemzadeh R, Jalali Farahani S, Azizi F. Childhood obesity in the Middle East: a review. Eastern Mediterranean Health Journal. 2010;16(9):1009-17.

8. Ziaee V, Kelishadi R, Ardalan G, Gheiratmand R, Majdzadeh S, Monazzam M. Physical activity in Iranian students CASPIAN Study. Iranian Journal of Pediatrics. 2006;16(2):157-64.

9. Payne VG, Isaacs LD. Human Motor Development: A Lifespan Approach: McGraw-Hill; 2002. 522 p.

10. Stodden DF, Goodway JD, Langendorfer SJ, Roberton MA, Rudisill ME, Garcia C, et al. A Developmental Perspective on the Role of Motor Skill Competence in Physical Activity: An Emergent Relationship. Quest. 2008;60(2):290-306.

11. Hume C, Okely A, Bagley S, Telford A, Booth M, Crawford D, et al. Does Weight Status Influence Associations Between Children's Fundamental Movement Skills and Physical Activity? Research Quarterly for Exercise and Sport. 2008;79(2):158-65.

12. Okely AD, Booth ML, Patterson JW. Relationship of cardiorespiratory endurance to fundamental movement skill proficiency among adolescents. Pediatric Exercise Science. 2010;13(4):380 - 91.

13. Wrotniak BH, Epstein LH, Dorn JM, Jones KE, Kondilis VA. The Relationship Between Motor Proficiency and Physical Activity in Children. Pediatrics. 2006;118(6):e1758-e65.

14. Morgan PJ, Okely AD, Cliff DP, Jones RA, Baur LA. Correlates of objectively measured physical activity in obese children. Obesity (Silver Spring, Md). 2008;16(12):2634-41.

15. Ulrich BD. Perceptions of Physical Competence, Motor Competence, and Participation in Organized Sport: Their Interrelationships in Young Children. Research Quarterly for Exercise and Sport. 1987;58(1):57-67.

16. Fisher A, Reilly JJ, Kelly LA, Montgomery C, Williamson A, Paton JY, et al. Fundamental movement skills and habitual physical activity in young children. Med Sci Sports Exerc. 2005;37(4):684-8.

17. Burton AW, Miller DE. Movement Skill Assessment: Human Kinetics; 1998. 407 p.

18. Ulrich DA. Test of Gross Motor Development - 2 (TGMD-2). Austin, TX: PRO-ED2000.

19. Zarezadeh M, Farokhi A, Kazem Nezhad A. Determining Reliability and Validity of Test of Gross Motor Development (Ulrich, 2000) In 3-11 Aged Children Of Tehran City. Olympic. 2011;18(4):85-98 [Article in Farsi].

20. Kowalski KC, Crocker P, Faulkner RA. Validation sf the physical activity questionnaire for older children. Pediatric exercise science. 1997;9(4):174-86.

21. Faghihimani Z, Nourian M, Nikkar AH, Farajzadegan Z, Khavariyan N, Ghatrehsamani S, et al. VALIDATION OF THE CHILD AND ADOLESCENT INTERNATIONAL PHYSICAL ACTIVITY QUESTIONNAIRES IN IRANIAN CHILDREN AND ADOLESCENTS2010.

22. Barnett LM, Morgan PJ, van Beurden E, Beard JR. Perceived sports competence mediates the relationship between childhood motor skill proficiency and adolescent physical activity and fitness: a longitudinal assessment. The International Journal of Behavioral Nutrition and Physical Activity. 2008;5:40-.

23. Okely A, Booth M. Relationship of enjoyment of physical activity and preferred activities to fundamental movement skill proficiency in young children. International Journal of Behavioral Medicine. 2000;7(Suppl. 1):151.

24. Gallahue DL, Ozmun JC. Understanding motor development: infants, children, adolescents, adults. 6th ed. Boston (MA): McGraw-Hill; 2006.

25. McKenzie TL, Sallis JF, Broyles SL, Zive MM, Nader PR, Berry CC, et al. Childhood movement skills: predictors of physical activity in Anglo American and Mexican American adolescents? Res Q Exerc Sport. 2002;73(3):238-44.

26. Cliff DP, Wilson A, Okely AD, Mickle KJ, Steele JR. Feasibility of SHARK: a physical activity skilldevelopment program for overweight and obese children. Journal of science and medicine in sport / Sports Medicine Australia. 2007;10(4):263-7.

27. Reilly JJ, Kelly L, Montgomery C, Williamson A, Fisher A, McColl JH, et al. Physical activity to prevent obesity in young children: cluster randomised controlled trial. BMJ. 2006;333(7577):1041. 
28. Barnett LM, van Beurden E, Morgan PJ, Brooks LO, Beard JR. Childhood motor skill proficiency as a predictor of adolescent physical activity. The Journal of adolescent health : official publication of the Society for Adolescent Medicine. 2009;44(3):252-9.

29. Sallis JF, Owen N. Physical Activity and Behavioral Medicine: SAGE Publications; 1998. 240 p.

30. Sallis JF, Prochaska JJ, Taylor WC. A review of correlates of physical activity of children and adolescents. Med Sci Sports Exerc. 2000;32(5):963-75. 
تازههاى علوم كاربردى ورزش

دوره سوم، شماره دوم

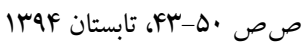

مقاله اصيل

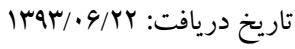

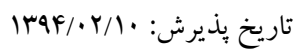

\section{ارتباط شايستكى مهارتهاى حر كتى و فعاليتبدنى دختران}

\section{'فاطمه خداوردى *' ‘عباس بجرام}

ا. كارشناس ارشد رفتار حركتى، گروه تربيتبدنى و علوم ورزشى، اداره آموزش و يرورش، منطقه ج، تهران، ايران.

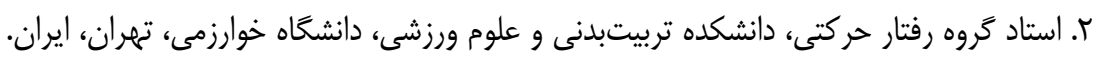

جكيده

در اين مطالعه ارتباط بين شايستخىهاى مهارت حركتى و فعاليت بدنى در دختران 9-1 سال بررسى شد. شايستخى در مهارتهاى كنترل شىء و جابجايى با استفاده از آزمون رشد حركتى درشت-r ارزيابى و فعاليت بدنى با استفاده از يرسشناملى فعاليت بدنى براى كودكان اندازهميرى شد.

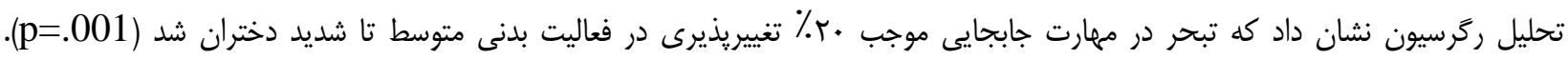

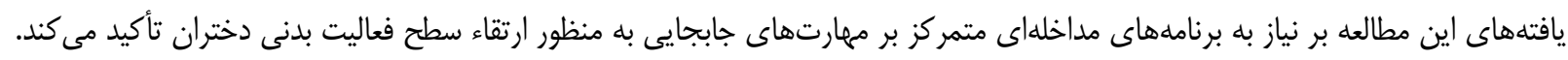
وازَّان كليدى: مهارت جابجايى، مهارت كنترل شى، دختران، فعاليت بدنى.

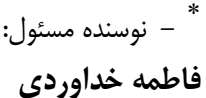

يست الكترونيك: khodaverdi_maryam@yahoo.com 